The Israeli Journal of Aquaculture - Bamidgeh, IJA_69.2017.1367. 15 pages

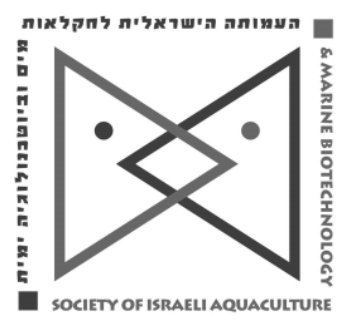

The IJA appears exclusively as a peer-reviewed on-line open-access journal at http://www.siamb.org.il. To read papers free of charge, please register online at registration form.

Sale of IJA papers is strictly forbidden.

\title{
Evaluation of the Dietary Effect of Hallabong Peel Oil on Growth, Hematological, and Immune Gene Expression in Rock Bream, Oplegnathus fasciatus Challenged with Edwardsiella tarda
}

\author{
Subramanian Dharaneedharan ${ }^{1} *$, Yeoung-Hwan Jang ${ }^{2}$, Dong-Hwi \\ $\mathrm{Kim}^{1}$, Chellam Balasundaram ${ }^{3}$, Moon-Soo Heo ${ }^{1} *$ \\ ${ }^{1}$ Marine Pathogenic Microbes and Aquatic Disease Control Lab, School of \\ Marine Life Sciences, Jeju National University, Jeju 690-756, South Korea. \\ ${ }^{2}$ Jeju Special Self-Governing Province Ocean and Fisheries Research \\ Institute, Pyoseon-myeon, Segwipo-si, Jeju 697-914, South Korea. \\ ${ }^{3}$ Department of Animal Science, Bharathidasan University, Tamil Nadu, \\ India.
}

Keywords: Hallabong; limonene; rock bream; immune gene; probiotic

\section{Abstract}

In the present study we evaluated the dietary effect of Hallabong peel oil (HPO) on growth, disease resistance, and immune gene expression of rock bream, Oplegnathus fasciatus challenged with Edwardsiella tarda after a 4 week feeding trial with 5 treatments: control-C, probiotic-P, HPO $(0.1 \%)$, HPO $(0.5 \%)$, and $\mathrm{P}+\mathrm{HPO}$, diets. All fish groups were assessed for growth performance, innate immune parameters, serum biochemical profile, and immune gene expression in head kidney on $2^{\text {nd }}$, and $4^{\text {th }}$ week, and $1^{\text {st }}, 3^{\text {rd }}$ and $7^{\text {th }}$ day post infection with Edwardsiella tarda. Fish fed the HPO enriched diets showed increased growth performance with significantly decreased $(P>0.05)$ mortality compared with the control and probiotic diet groups. The positive effects of HPO enriched diet were also found in all assessed innate immune and biochemical parameters which included increased respiratory burst and lysozyme activity, with significantly increased erythrocyte and leukocytes counts, increased serum protein, decreased glucose, triglycerides, cholesterol level in serum compared with control diet fed fish. Moreover, the probiotic bacterial count in the intestine of fish was enhanced with the HPO diet and the P+HPO diet compared to fish fed the probiotic diet. The head kidney of HPO enriched diet fed fish showed up-regulated expression of inflammatory cytokines genes such as TNFa, IL-1 $\beta$, and FST, after $4^{\text {th }}$ week of feeding trial which was increased $\sim 2$ to 3 times on $1 \mathrm{dpi}$ and $3 \mathrm{dpi}$. These results indicate that limonene rich $(91.26 \%)$, HPO enriched diets enhance growth and immunity and enhance disease resistance of Oplegnathus fasciatus challenged against E. tarda.

*Corresponding author: Email - msheo@jejunu.ac.kr; Tel: +8264543473; Fax: $+82647563$ 


\section{Introduction}

Due to several bacterial and viral diseases, aquaculture industries worldwide have suffered significant production losses (Wiens, 2009) either through mass mortality, decreasing growth and reproduction efficiency, or deteriorating quality of the final food product (FAO, 2013). Hence, more adequate preventive methods are required to maintain healthy aquaculture and to limit the outbreak of infectious diseases which threaten the stability of this vital food industry.

Several attempts have been made to control microbial infections by administering prophylactic and chemotherapeutic antimicrobial treatments (Cantas et al., 2013). Most of these agents are toxic, non-biodegradable, increase environmental pollution, and at times are not effective due to pathogen resistance (Shak et al., 2011). Disease outbreaks coupled with restricted use of chemical antibiotics have increased efforts to find other antibiotic alternatives.

In recent years, interest in the use of bioactive herbal immunostimulants (Bhuvaneswari, 2006), pro- and pre-biotics to improve the health status and to prevent and/or control pathogenic infection of fish, have greatly increased (Ganguly et al., Dimitroglou et al., 2011) Some herbal immunostimulants may disrupt the bacterial cell wall of pathogens, block the cellular metabolism, inhibit secretion of enzymes and interfere with bacterial signaling mechanism via quorum sensing (Citarasu, 2010). Several studies have reported the application of herbal extracts as phytobiotics, ecofriendly alternatives to chemical antibiotics for aquaculture species. These include, oregano essential oil, Origanum heracleoticum in channel catfish, Ictalurus panctatus (Zheng et al., 2009); lupin, Lupinus perennis, and mango, Mangifera indica in rainbow trout, Oncorhynchus mykiss (Awad et al., 2010); Rubus coreanus in Pacific Whiteleg shrimp, Penaeus vannamei (Subramanian et al., 2013), and white mulberry, Morus alba foliage methanolic extract in African Catfish, Clarias gariepinus (Sheikhlar et al., 2014).

Jeju hallabong (Citrus kiyomi $\times$ ponkan), is a hybrid seedless citrus fruit generally consumed throughout Korea and commonly known as 'Hallabong' named after Hallasan, the mountain where it was first grown since 1998 (Song et al., 2005; Kim et al., 2006). Hallabong is known for its sweet taste (sugar level above $12^{\circ} \mathrm{Bx}$ and acid content below $1.1 \%$ ), large size and as a rich source of vitamin C (Lee et al., 2012). Studies on the effect of citrus peel essential oil in aquaculture are scarce. Hence, the present study was conducted to determine the dietary effect of Hallabong peel oil (HPO) on the growth, hematological and immune gene expression in rock bream, Oplegnathus fasciatus challenged with Edwardsiella tarda.

\section{Materials and methods}

Fish. Healthy cultured rock bream, Oplegnathus fasciatus $(25.4 \pm 0.13 \mathrm{~g}, n=400)$ were obtained from a local fish farm in Jeju Island, Republic of Korea. The fish were transported and reared in a recirculating culture system in the Department of Aquatic Biomedical Science, Jeju National University. The recirculating culture system consisted of fifteen $1000 \mathrm{~L}$ circular tanks and one $1000 \mathrm{~L}$ filter tank with continuous aeration and temperature control. Culture water was partially replaced with sand filtered water once a week. The measured water quality parameters were: salinity $330.7 \mathrm{ppt}, \mathrm{pH} 7.50 .6$, dissolved oxygen $8.40 .6 \mathrm{mg} / \mathrm{L}$, ammonia $0.006 \mathrm{mg} / \mathrm{L}$, and photoperiod of $14 \mathrm{~h}$ light: $10 \mathrm{~h}$ dark cycle. Fish were fed a basal diet ad libitum twice a day at 09:00 and 15:00 $\mathrm{h}$ at a rate of $5 \%$ of their body weight (Table 1 ).

Plant materials and peel oil extraction. Fresh Hallabong fruit were purchased from Jeju Island traditional market and the peel oil sample was prepared following the cold press method described by Choi and Sawamura (2001). Briefly, the mesocarp and albedo layers were peeled from $\sim 5 \mathrm{~kg}$ of fresh Hallabong and the peel oil (PO) was extracted by hand-pressing the flavedo, collected in brine solution on ice. Then the oil extract was centrifuged at $4000 \mathrm{~g}$ for $15 \mathrm{mins}$ at $4^{\circ} \mathrm{C}$ and the supernatant was dehydrated with anhydrous sodium sulphate at $4^{\circ} \mathrm{C}$ for 24 hours and stored at $-25^{\circ} \mathrm{C}$ until further use. 
Table 1. Formulation and proximate composition of rock beam $O$. fasciatus diet.

\begin{tabular}{ll}
\hline Ingredients $(\mathrm{g} / 100 \mathrm{~g}$ diet) & Composition $(\%)$ \\
\hline Fish meal & 57.0 \\
Wheat flour & 20.0 \\
Soy bean oil & 5.7 \\
Fish oil $^{\mathrm{a}}$ & 5.3 \\
Mineral premix $^{\mathrm{c}}$ & 2.5 \\
Vitamin premix $^{\mathrm{d}}$ & 3.0 \\
Cellulose $^{\mathrm{b}}$ & 2.5 \\
Binder & 2.0 \\
Antifungi & 0.3 \\
Antioxidant & 0.35 \\
Proximate composition (\%) & \\
Crude protein & 39.48 \\
Crude Lipid & 19.7 \\
Ash & 9.7 \\
Fiber & 2.7 \\
Moisture & 8.2 \\
NFE & 17.9 \\
Gross energy $(\mathrm{MJ} / \mathrm{kg})$ & 22.06 \\
\hline
\end{tabular}

${ }^{a}$ E-Wha oil, Pusan, Korea

b United States Biochemical (Cleveland, OH) 44122

c Premix ( $\mathrm{g} / 100 \mathrm{~g})$ contains DL-calcium pantothenate, 0.5 ; choline bitartrate, 10; inositol, 0.5 ; menadione, 0.02 ; niacin, 0.5 ; pyridoxine $-\mathrm{HCl}, 0.1$; riboflavin, 0.1 ; thiamine mononitrate, $0.1 ; \mathrm{DL}-$ a-tocopheryl acetate, 0.2 ; retinyl acetate, 0.02 ; biotin, 0.01 ; folic acid, 0.02; B12, 0.0002; Cholecalciferol, 0.008 ; a-cellulose, 85.0.

${ }^{d} \operatorname{Premix}(\mathrm{g} / 100 \mathrm{~g})$ contains Al, 0.12; $\mathrm{Ca}, 500 ; \mathrm{Cl}, 10 ; \mathrm{Cu}, 0.5 ; \mathrm{Co}, 0.9 ; \mathrm{Na}, 0.13 ; \mathrm{Mg}, 50 ; \mathrm{P}, 5000 ;$ $\mathrm{K}, 425 ; \mathrm{Zn}, 0.3 ; \mathrm{Fe}, 4 ; \mathrm{I}, 0.5$, Se, 0.02; $\mathrm{Mn}, 0.9$.

e Nitrogen-free extracts (NFE) = dry matter - (crude protein + crude lipid + ash + fibre).

${ }^{\mathrm{f}}$ Gross energy $(\mathrm{MJ} / \mathrm{kg}$ ) calculated according to $23.6 \mathrm{~kJ} / \mathrm{g}$ for protein, $39.5 \mathrm{~kJ} / \mathrm{g}$ for lipid and17.0 $\mathrm{kJ} / \mathrm{g}$ for NFE.

Gas chromatography-mass spectrometry analysis (GC-MS) Peel oil. One $\mu$ l of extracted oil was injected and analyzed by GC-MS. The chemical composition of the hallbong peel oil was determined by the Technological Development Center (PADETEC) of the Federal University of Ceara using GC-MS with a Hewlett-Packard 5971 GC/MS apparatus (Avondale, PA, USA) under the following conditions: a $0.25 \mathrm{~mm} \times 30 \mathrm{~m}$ polydimethylsiloxane DB-1 fused silica capillary column with a film thickness of $0.10 \mu \mathrm{m}$; helium as the carrier gas $(1 \mathrm{ml} / \mathrm{min})$; injector temperature of $250^{\circ} \mathrm{C}$; detector temperature of $200^{\circ} \mathrm{C}$. The column temperature ranged from $35-180^{\circ} \mathrm{C} / \mathrm{min}$ at $4{ }^{\circ} \mathrm{C}$ $\mathrm{V} / \mathrm{min}$, then $180-280^{\circ} \mathrm{C}$ at $20^{\circ} \mathrm{C} \mathrm{V} / \mathrm{min}$. Mass spectra were obtained by electronic impact $70 \mathrm{eV}$. The compounds were identified by comparing their retention indices (RRI) with those reported in related literature and by comparison of their mass spectra with the Wiley library (Lin et al., 1999) or published mass spectra (Massada, 1976).

Experimental diet. Five different experimental diets: control $(C)$, probiotic $(P)$, $0.1 \% \mathrm{HPO}, 0.5 \% \mathrm{HPO}$, and P+HPO, were prepared with commercial rock bream feed (Suhyup, S.Korea) according to Dairiki et al. (2013) with grain alcohol (known as ethyl alcohol) as a diluent for the hallabong peel oil. Proximate composition of the commercial feed was $35.5 \mathrm{~g} / \mathrm{kg}$ crude protein, $120 \mathrm{~g} / \mathrm{kg}$ moisture, $47 \mathrm{~g} / \mathrm{kg}$ crude lipid, and $30 \mathrm{~g} / \mathrm{kg}$ crude fiber. For every $\mathrm{kg}$ of feed, a portion of HPO in $100 \mathrm{ml}$ of grain alcohol ( $100 \mu \mathrm{L}$ for $0.1 \% \mathrm{HPO}$ and $500 \mu \mathrm{L}$ for $0.5 \% \mathrm{HPO}$ ) was sprinkled and mixed thoroughly. One $\mathrm{kg}$ of probiotic diet received $95 \mathrm{ml}$ of grain alcohol, was left to dry for 2 hrs after which $5 \mathrm{ml}$ of $1.4 \times 10^{6} \mathrm{CFU} / \mathrm{mL}$ of Lactobacillus planctarum (KCTC3104) was held in sterile saline. The control diet was mixed with $100 \mathrm{ml} / \mathrm{Kg}$ of grain alcohol. Similarly the P+HPO diet was mixed with $95 \mathrm{ml}$ of grain alcohol, $250 \mu \mathrm{L}(0.25 \%)$ of HPO, and $4.75 \mathrm{~mL}$ of $1.4 \times 10^{3} \mathrm{~mL}$ of probiotic bacterial cells prepared in sterile saline. The feeds were allowed to dry at $18^{\circ} \mathrm{C}$ under sterile conditions for $24 \mathrm{~h}$ after which they were packed in air tight plastic bags and stored at $-18^{\circ} \mathrm{C}$.

Feeding regime. A total of 400 fish were randomly divided into four diet groups (50 fish per group). Three replicate feeding experiments were conducted over seven 
weeks ( 28 days of feeding trial and 21 days post challenge (dpi) with $E$. tarda). All fish groups were assessed for growth and serum biochemical parameters along with immune gene expression in head kidney using five randomly collected fish from each diet group (in triplicate) at the end of the $2^{\text {nd }}$ and $4^{\text {th }}$ week of feeding experiment and $1^{\text {st }}, 3^{\text {rd }}$, and $7^{\text {th }}$ day of post infection (dpi).

Growth performance. All fish were deprived of food $24 \mathrm{~h}$ before sampling.

Then the following parameters were measured at the end of the feeding trial ( 4 weeks): Weight gain $=W_{2}(g)-W_{1}(g)$; Specific growth rate $(S G R)=100\left(\ln W_{2}-\ln W_{1}\right) T^{1}$; Feed conversion ratio $(F C R)=$ feed intake/weight gain $(g)$; Survival rate $(\%)=($ final amount of fish/initial amount of fish) $\times 100$;

Where $W_{1}$ is the initial weight, $W_{2}$ is the final weight and $T$ is the number of days in the feeding period.

Blood sampling and analysis. At the end of four weeks of the feeding trial, and $1^{\text {st }}$, $3^{\text {rd }}$, and $7^{\text {th }}$ day after pathogenic challenge (dpi), blood samples (approximately $0.5 \mathrm{ml}$ ) of six fish/group were collected randomly from caudal vein using a vacutainer fitted $1 \mathrm{ml}$ 27-G needle. Individual fish were anesthetized with $\mathrm{MS}-222\left(\mathrm{NaHCO}_{3}\right.$ and tricaine methanesulphonate; Sigma Chemicals) $1: 4000$ in dechlorinated water for 2 min. Individual fish were sampled only once to avoid the influence on the assays due to multiple bleeding and handling stress on the fish. To evaluate the blood physiological parameters and immunological assay, feeding was ceased for $24 \mathrm{~h}$ prior to sampling. Half of each blood sample was immediately used for hematological examination, while the other half was mixed with heparin anticoagulant and kept frozen at $4^{\circ} \mathrm{C}$. The serum tubes were placed at room temperature and allowed to clot for $2 \mathrm{~h}$. Sera were separated by centrifugation at $1500 \mathrm{~g}$ for $20 \mathrm{~min}$ and sera from the same groups were pooled before being stored at $-70^{\circ} \mathrm{C}$ for biochemical and immunological analyses.

Erythrocyte and leukocyte count. Total erythrocyte and leukocyte counts were measured with a Neubauer hemocytometer in blood samples diluted in Hayem's and Turke's solution, respectively (Harikrishnan et al., 2003).

Respiratory burst activity. Respiratory burst activity was measured following Pieters et al. (2008). Fifty microlitres of blood was pipetted into the wells of ' $U$ ' bottom microtitre plates (NalgeNunc) and incubated for $1 \mathrm{~h}$ at room temperature to facilitate adhesion of the cells. The supernatant was gently removed and the adhered cells were washed three times with PBS. After washing, $50 \mu \mathrm{l}$ of $0.2 \%(\mathrm{w} / \mathrm{v})$ nitroblue tetrazolium (NBT, Sigma-Aldrich) in PBS was added to the wells and incubated for $1 \mathrm{~h}$ at room temperature. The supernatant was removed, and the cells were fixed with $100 \%(\mathrm{v} / \mathrm{v})$ methanol for $3 \mathrm{~min}$, and then washed three times with $30 \%(\mathrm{v} / \mathrm{v})$ methanol. The plates were air-dried before $60 \mu \mathrm{l}$ of $2 \mathrm{M}$ potassium hydroxide $(\mathrm{KOH}$, Sigma-Aldrich) and $70 \mu \mathrm{l}$ dimethyl sulphoxide (DMSO, Sigma-Aldrich) were added to each well to dissolve the formazan blue crystals. The optimal density (OD) of the resulting solution was read in a microplate reader at $550 \mathrm{~nm}$ against a $\mathrm{KOH} / \mathrm{DMSO}$ blank.

Serum biochemistry. Serum biochemical parameters, such as serum aspartate aminotransferase (AST), alanine aminotransferase (ALT) activities, low density cholesterol (LDL), triglycerides (TG), hemoglobin $(\mathrm{Hb})$, concentration of total protein (TP) and glucose (GLU), were determined in ch100 plus a blood chemistry autoanalyzer (DaeKwang Meditech, Korea) following manufacturer's instructions.

Lysozyme activity. The serum lysozyme activity was measured spectrophotometrically according to method of Ellis (1990). A suspension of Micrococcus lysodeikticus $0.02 \%(\mathrm{w} / \mathrm{v})$ made up in $0.05 \mathrm{M}$ PBS at $\mathrm{pH} 6.2$ was used as substrate. Lyophilised hen egg white lysozyme was used as a standard. A standard curve was prepared for each assay. Standard solutions as well as samples were added to the substrate at $25^{\circ} \mathrm{C}$. The results are expressed as $\mu \mathrm{g} / \mathrm{ml}$ equivalent of hen egg white lysozyme activity.

Intestinal microbiological analysis. Microfloral analyses were performed following Nikoskelainen et al. (2003) the difference being that the fish were starved for $30 \mathrm{~h}$ before sampling. The probiotic strain counts in the posterior intestines of fish were determined 
by plate counting on MA. Six fish for each treatment and time were used for these studies.

Real-Time immune gene expression analysis using qPCR. For qPCR analysis of immune gene expression, total RNA was extracted from head kidney samples dissected from each experimental diet group at the end $2^{\text {nd }}$ and $4^{\text {th }}$ week of feeding trial $\left(10^{\text {th }}\right.$ week) and $1^{\text {st }}, 3^{\text {rd }}$ and $7^{\text {th }}$ day post infection (dpi) with $E$. tarda using the RNeasy Mini Kit (Qiagen) according to the manufacturer's instructions. To amplify rock bream immune genes such as Tumour necrosis factor-alpha (TNFa), FST, Cox-2, INF1 and IL-1 $\beta$ along with the internal control gene $\beta$-actin, primers were designed based on previous reports (Table. 2) and all primers were produced by Bioneer Corporation Public CO., Ltd. (Daejeon, South Korea).

Table 2. Primers used for the real-time PCR assay of five immune genes and one internal control $\beta$-actin gene of rock bream, Oplegnathus fasciatus.

\begin{tabular}{|c|c|c|c|c|}
\hline & Gene & Primer sequences $\left(5^{\prime}\right.$ to $\left.3^{\prime}\right)$ & Product size (bp) & Reference \\
\hline 1 & $\begin{array}{l}\text { TNFa- Fw } \\
\text { TNFa- Rev }\end{array}$ & $\begin{array}{l}\text { GATCGCCTCTCCTGATGTTC } \\
\text { ACCACCAAGCTGATGGTTTC }\end{array}$ & 152 & Hong et al., 2016 \\
\hline 2 & $\begin{array}{l}\text { IL-1b- Fw } \\
\text { IL-1b- Rev }\end{array}$ & $\begin{array}{l}\text { ATCTGGAGACGGTGGACAAC } \\
\text { GCTGATGTACCAGTCGCTGA }\end{array}$ & 142 & Hong et al., 2016 \\
\hline 3 & $\begin{array}{l}\text { FST- FW } \\
\text { FST- Rev }\end{array}$ & $\begin{array}{l}\text { GCTATGCTGCTGACCGCAATGA } \\
\text { GCGTAGGACTGCAACTCCACAAC }\end{array}$ & 103 & Herath et al., 2015 \\
\hline 4 & $\begin{array}{l}\text { CoX-2- Fw } \\
\text { CoX-2- Rev }\end{array}$ & $\begin{array}{l}\text { ACCTTGTGGAGTCGTTCACC } \\
\text { CATGGAGAATCGCTTCCTGT }\end{array}$ & 154 & Hong et al., 2016 \\
\hline 5 & $\begin{array}{l}\text { INF1- FW } \\
\text { INF1- Rev }\end{array}$ & $\begin{array}{l}\text { GTGAAAACTCTITGGATCTACTGGACACG } \\
\text { GTGAAACCAAGTTTATCCTCAGCTGCTG }\end{array}$ & 146 & Hong et al., 2016 \\
\hline 6 & $\begin{array}{l}\beta \text {-actin- Fw } \\
\beta \text {-actin-Rev }\end{array}$ & $\begin{array}{l}\text { TCATCACCATCGGCAATGAGAGGT } \\
\text { TGATGCTGTTGTAGGTGGTCTCGT }\end{array}$ & 98 & Bae et al., 2013. \\
\hline
\end{tabular}

qPCR was carried out in the M×3000P Real-time PCR System (Stratagene, USA) using SYBR Green. Amplifications were performed in a 96 -well plate in a $25 \mu \mathrm{L}$ reaction volume containing $12.5 \mu \mathrm{L}$ of $2 \times$ Brilliant III Ultr-Fast SYBR ${ }^{\circledR}$ Green Master Mix (Agilent Technologies), $2.5 \mu \mathrm{L}$ (each) of the forward and reverse primers $(10 \mu \mathrm{M}), 1.5 \mu \mathrm{L}$ of template $(0.1 \mu \mathrm{g} \mathrm{CDNA})$, and $5 \mu \mathrm{L}$ of DEPC-water. The thermal profile for qPCR was $95^{\circ} \mathrm{C}$ for $10 \mathrm{~min}$, followed by 25 cycles of $95^{\circ} \mathrm{C}$ for $30 \mathrm{~s}, 60^{\circ} \mathrm{C}$ for $60 \mathrm{~s}$, and $72^{\circ} \mathrm{C}$ for $60 \mathrm{~s}$. After PCR amplification, melt-curve analysis was conducted with a thermal profile cycle of $95^{\circ} \mathrm{C}$ for $60 \mathrm{~s}, 55^{\circ} \mathrm{C}$ for $30 \mathrm{~s}$, and $95^{\circ} \mathrm{C}$ for $30 \mathrm{~s}$, to confirm that there was only one amplified product and its size was verified on ethidium bromide-stained $2 \%$ agarose gels in Tris acetate-EDTA buffer. Data analysis of the qPCR was performed with the MxPro Mx3000P Multiplex Quantitative PCR system Software. The qPCR standard curve of each gene was prepared using the plasmid vector containing $O$. fasciatus specific cDNA fragment as a template. It calculated the relative expression ratio $(R)$ of mRNA according to the formula $2^{-\Delta \Delta \mathrm{Ct}}=2^{-(\Delta \mathrm{Ct} \text { (test)- } \Delta \mathrm{Ct}(\beta \text {-actin)) }}$ (Livak and Schmittgen, 2001). Real-time PCR efficiencies were acquired by the amplification of dilution series of cDNA according to the equation $10^{(-1 / \text { slope })}$ and were consistent between target genes and $\beta$-actin. The results are presented as means with standard deviations.

Statistics. The data (mean $\pm \mathrm{SE}$, standard error) were analyzed by one way analysis of variance (ANOVA) followed by Tukey's test to compare the means between individual treatments with SPSS (Ver. 22.0) at $P<0.05$ levels.

\section{Results}

GC analysis of HPO components. Extracted phytochemicals and their relative percentages in the HPO are provided in figure 1 . More than thirteen major compounds were detected by GC the most abundant constituent being limonene $(91.26 \%)$ followed by sabinene $(1.63 \%)$, myrcene $(1.17 \%)$, and terpinene $(0.86 \%)$. 


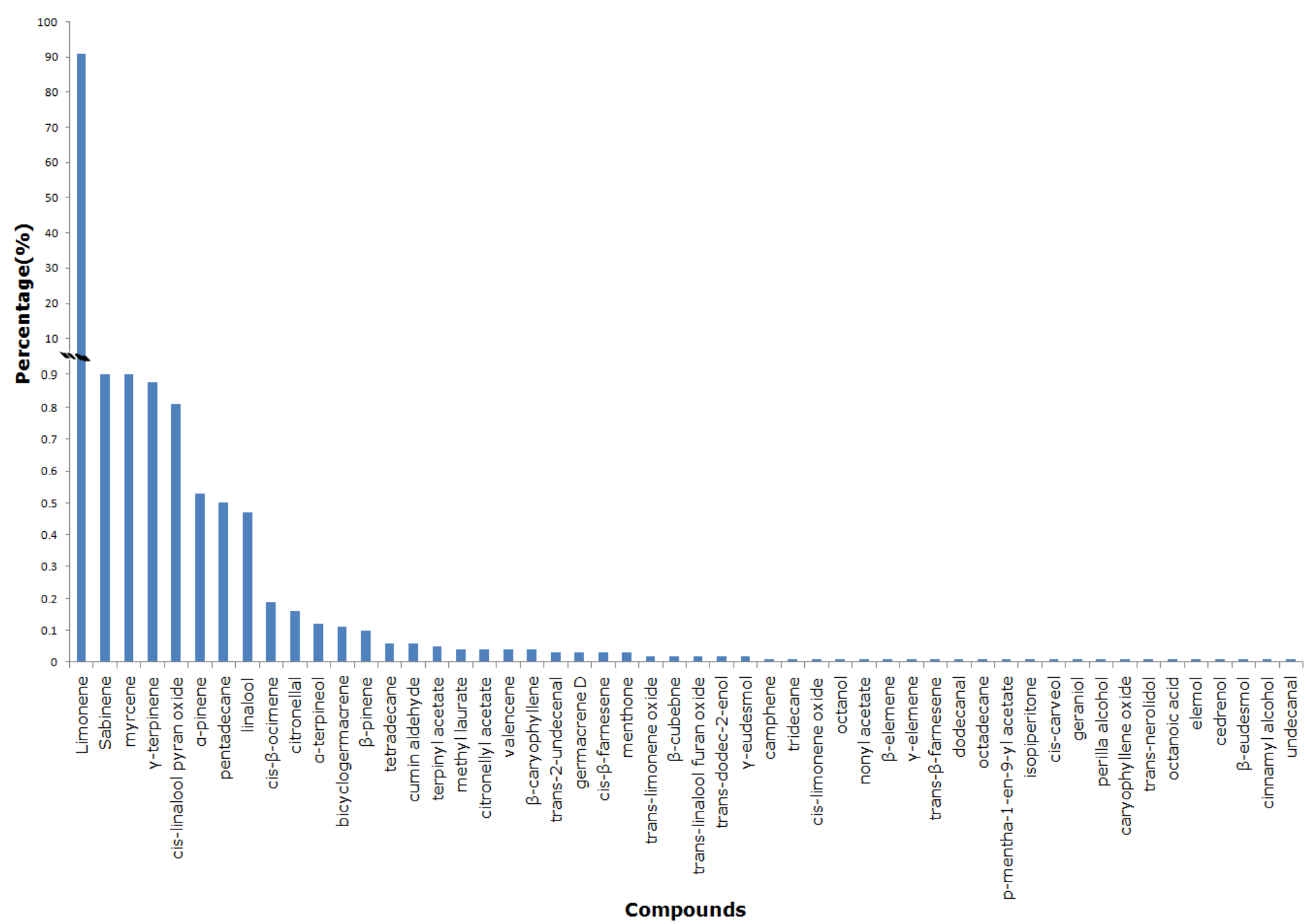

Fig.1. Composition of Hallabong peel oil in percentages (\%).

Growth performance and disease resistance. Fish from all experimental diet groups showed a significant increase $(P<0.05)$ in weight gain percentages compared to the control diet fed fish. However, among the experimental diet fish groups, the $0.5 \%$ HPO and P+HPO diet fed fish showed greater increased WG than the P and $0.1 \%$ HPO diet fish groups. Disease resistance against $E$. tarda was significantly $(P<0.05)$ increased, and mortality decreased in the HPO diet fed groups compared to the probiotic and control diet fed fish (Table 3).

Dietary effect of HPO on fish erythrocyte and leukocytes count. Erythrocyte count (EC) increased with increasing concentration of HPO enriched diet compared to the control diet fed fish in both uninfected and challenged groups (Table 4). A similar pattern of increasing leukocyte count (LC) was found in HPO diet enriched fish groups when compared with those of the control and probiotic diet fed fish. However, P+HPO diet fed fish showed significant $(P<0.05)$ increases in both EC and LC compared to the control and probiotic diet fish groups. 
Table 3. Growth performance of Oplegnathus fasciatus fed with diets enriched with Hallabong peel oil for 4 weeks.

\begin{tabular}{llllll}
\hline Index & C diet & $P$ diet & $0.1 \% H P O$ diet & $0.5 \% H P O$ diet & $P+H P O$ \\
\hline WG (\%) & $23.16 \pm 1.14^{\mathrm{c}}$ & $32.76 \pm 1.32^{\mathrm{b}}$ & $35.56 \pm 0.14^{\mathrm{ab}}$ & $36.87 \pm 0.11^{\mathrm{a}}$ & $35.51 \pm 1.04^{\mathrm{ab}}$ \\
SGR & $2.22 \pm 0.09^{\mathrm{c}}$ & $2.56 \pm 0.14^{\mathrm{b}}$ & $2.59 \pm 0.1^{\mathrm{ab}}$ & $2.62 \pm 0.32^{\mathrm{a}}$ & $2.60 \pm 0.17^{\mathrm{ab}}$ \\
FCR & $2.18 \pm 0.22^{\mathrm{c}}$ & $1.86 \pm 0.20^{\mathrm{ab}}$ & $1.85 \pm 0.07^{\mathrm{ab}}$ & $1.89 \pm 0.21^{\mathrm{a}}$ & $1.83 \pm 0.11^{\mathrm{b}}$ \\
SR $(\%)$ & $53 \pm 0.11^{\mathrm{c}}$ & $78 \pm 0.32^{\mathrm{ab}}$ & $84 \pm 0.14^{\mathrm{a}}$ & $85 \pm 0.31^{\mathrm{a}}$ & $81 \pm 0.12^{\mathrm{ab}}$
\end{tabular}

*Data are presented as mean \pm S.D $(n=5)$. Values in each row with different superscripts shows significant difference $(P<0.05)$. WG, weight gain; SGR, specific growth rate; FCR, feed conversion ratio; SR, survival rate.

Table 4. Hematological and biochemical indices of Oplegnathus fasciatus fed with diets enriched with Hallabong peel oil for 4 weeks of feeding trial and 7 days of post challenged with E. tarda.

\begin{tabular}{llllll}
\hline Parameters & C diet & $P$ diet & $0.1 \% H P O$ diet & $0.5 \% H P O$ diet & $P+H P O$ \\
\hline Erythrocytes $\left(10^{6} / \mathrm{mm}^{3}\right)$ & $0.83 \pm 0.12^{\mathrm{c}}$ & $0.92 \pm 0.18^{\mathrm{b}}$ & $0.97 \pm 0.21^{\mathrm{ab}}$ & $1.06 \pm 0.11^{\mathrm{a}}$ & $0.96 \pm 0.13^{\mathrm{ab}}$ \\
Leukocytes $\left(10^{3} / \mathrm{mm}^{3}\right)$ & $11.7 \pm 0.5^{\mathrm{c}}$ & $12.2 \pm 0.7^{\mathrm{b}}$ & $15.41 \pm 0.11^{\mathrm{ab}}$ & $19.17 \pm 0.13^{\mathrm{a}}$ & $14.02 \pm 0.22^{\mathrm{ab}}$ \\
Aspartate aminotransferase & $48.24 \pm 0.15^{\mathrm{c}}$ & $29.27 \pm 0.14^{\mathrm{b}}$ & $27.25 \pm 0.19^{\mathrm{ab}}$ & $24.02 \pm 0.07^{\mathrm{a}}$ & $26.42 \pm 0.12^{\mathrm{ab}}$ \\
Alanine aminotransferase $(\mathrm{IU} / \mathrm{L})$ & $3.27 \pm 0.21^{\mathrm{c}}$ & $2.3 \pm 0.11^{\mathrm{b}}$ & $2.1 \pm 0.13^{\mathrm{ab}}$ & $1.94 \pm 0.18^{\mathrm{a}}$ & $2.17 \pm 0.22^{\mathrm{ab}}$ \\
LDL cholesterol $(\mathrm{g} / \mathrm{dL})$ & $124.21 \pm 0.15^{\mathrm{c}}$ & $82.12 \pm 0.17^{\mathrm{b}}$ & $74.24 \pm 0.21^{\mathrm{ab}}$ & $52.11 \pm 0.2^{\mathrm{a}}$ & $57.43 \pm 0.14^{\mathrm{ab}}$ \\
Triglycerides $(\mathrm{mg} / \mathrm{dL})$ & $38.41 \pm 0.14^{\mathrm{c}}$ & $33.12 \pm 0.15^{\mathrm{b}}$ & $29.24 \pm 0.05^{\mathrm{ab}}$ & $23.94 \pm 0.12^{\mathrm{a}}$ & $30.41 \pm 0.3^{\mathrm{ab}}$ \\
Total protein $(\mathrm{g} / \mathrm{dL})$ & $2.92 \pm 0.14^{\mathrm{c}}$ & $3.78 \pm 0.24^{\mathrm{b}}$ & $4.12 \pm 0.07^{\mathrm{ab}}$ & $4.61 \pm 0.27^{\mathrm{a}}$ & $4.22 \pm 0.31^{\mathrm{ab}}$ \\
Glucose $(\mathrm{g} / \mathrm{dL})$ & $84.25 \pm 0.5^{\mathrm{c}}$ & $51.04 \pm 0.03^{\mathrm{b}}$ & $44.21 \pm 0.7^{\mathrm{ab}}$ & $43.11 \pm 0.02^{\mathrm{a}}$ & $46.2 \pm 0.06^{\mathrm{ab}}$ \\
\hline
\end{tabular}

*Data are presented as mean \pm S.D $(n=5)$. Data in the same row with different superscript are significantly different $(p<0.05)$.

Respiratory burst activity. Figure 2 shows the respiratory burst activity of uninfected and challenged fish fed with control, probiotic, and HPO enriched diets. The blood respiratory burst level was significantly enhanced $(P<0.05)$ in both $0.1 \%$ and $0.5 \%$ HPO diet fed fish followed by P+HPO diet fed fish for one week compared to the control and probiotic diet fish.

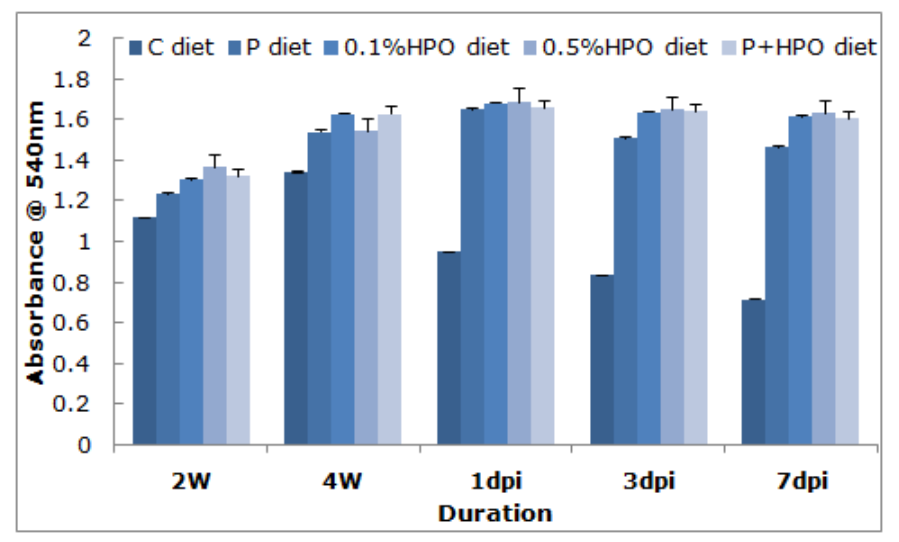

Fig.2. Respiratory burst activity of pre- and post-challenged rock bream fed with control - $\mathrm{C}$ diet, probiotic - P diet, HPO enriched diet $-0.1 \%$, HPO enriched diet $-0.5 \%$, and P+HPO diets for 36 days. $\mathrm{n}=5$ in triplicate.

Serum biochemistry and lysozyme activity. Biochemical responses of uninfected and challenged rock bream fed with control, probiotic, and HPO enriched, diets are shown in Table 5. Total serum protein level of fish fed with HPO and P+HPO diets, increased significantly $(P<0.05)$ while other parameters such as total glucose, AST, ALT, triglycerides, low density cholesterol levels decreased significantly $(P<0.05)$ compared to the probiotic and control diet fed fish groups. However, serum lysozyme activity was significantly enhanced $(P<0.05)$ in all the experimental diet fed fish when compared with the control diet fed fish (Fig. 3). However in the HPO enriched diet fed fish it differed significantly $(P<0.05)$ from the probiotic diet group. 


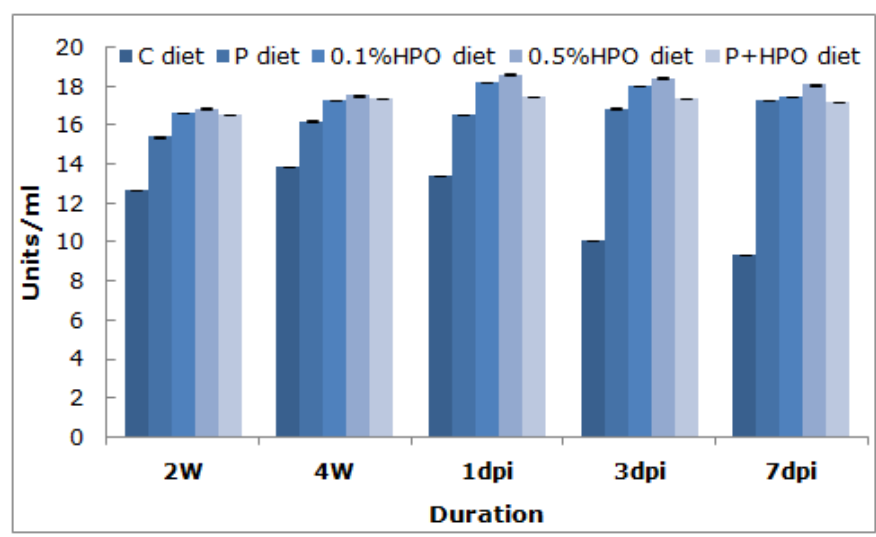

Fig.3. Lysozyme activity of pre- and post-challenged rock bream fed with control $-\mathrm{C}$ diet, probiotic $-\mathrm{P}$ diet, HPO enriched diet $(0.1 \%)$, HPO enriched diet $(0.5 \%)$, and P+HPO diet for 36 days. $n=5$ in triplicate.

Intestinal microflora. No bacterial species were detected in the intestine of control, $0.1 \%$ and $0.5 \% \mathrm{HPO}$ diet fed fish after four weeks of the feeding trial. The probiotic and $\mathrm{P}+\mathrm{HPO}$ diet fed fish groups showed $2.4 \times 10^{3}$ and $3.2 \times 10^{3}$ cells which increased to $4.4 \times 10^{5}$ and $8.6 \times 10^{6}$ cells after challenge with E. tarda. (Table 5).

Table 5. Lactobacillus planctarum cell counts of rock bream, after 4 weeks of feeding trial and 3 weeks post challenge with $E$. tarta.

\begin{tabular}{llllll}
\hline Weeks & C diet & P diet & $\begin{array}{l}0.1 \% \mathrm{HPO} \\
\text { diet }\end{array}$ & $\begin{array}{l}0.5 \% \mathrm{HPO} \\
\text { diet }\end{array}$ & $\mathrm{P}+\mathrm{HPO}$ \\
\hline $1^{\text {st }}$ & ND & $2.4 \times 10^{3}$ & ND & ND & $3.2 \times 10^{3}$ \\
$2^{\text {nd }}$ & ND & $3.2 \times 10^{2}$ & ND & ND & $3.5 \times 10^{4}$ \\
$3^{\text {rd }}$ & ND & $3.6 \times 10^{3}$ & ND & ND & $4.1 \times 10^{4}$ \\
$4^{\text {th }}$ & ND & $3.7 \times 10^{3}$ & ND & ND & $5.6 \times 10^{5}$ \\
$5^{\text {th }}$ & ND & $4.2 \times 10^{4}$ & ND & ND & $6.4 \times 10^{5}$ \\
$6^{\text {th }}$ & ND & $4.4 \times 10^{5}$ & ND & ND & $3.6 \times 10^{6}$ \\
$7^{\text {th }}$ & ND & $3.6 \times 10^{4}$ & ND & ND & $8.6 \times 10^{6}$ \\
\hline
\end{tabular}

Immune gene response for HPO enriched diet. Dietary inclusion of HPO significantly enhanced the mRNA expression of immune related genes namely TNF-a, FST, and IL-1 1 (Fig. 4), on $2^{\text {nd }}$ and $4^{\text {th }}$ weeks when compared with probiotic and control diet groups. HPO and P+HPO diets increased the synthesis of TNF-a, FST, and IL-1 $\beta$ transcript which were enhanced $\sim 2$ to 3 times on 1dpi and 3dpi and gradually decreased on 7dpi. However, in probiotic diet fed fish, immune gene enhancement commenced on $3 \mathrm{dpi}$ and reduced on 7dpi particularly in TNF-a, FST, and IL-1 $\beta$ gene. The expression level of Cox2 and INF1 gene showed no significant variation $(P<0.05)$ among the experimental diet fed fish groups; however their expression level was found to be significantly enhanced $(P<0.05)$ when compared with control diet fed fish group (Fig. 5). 

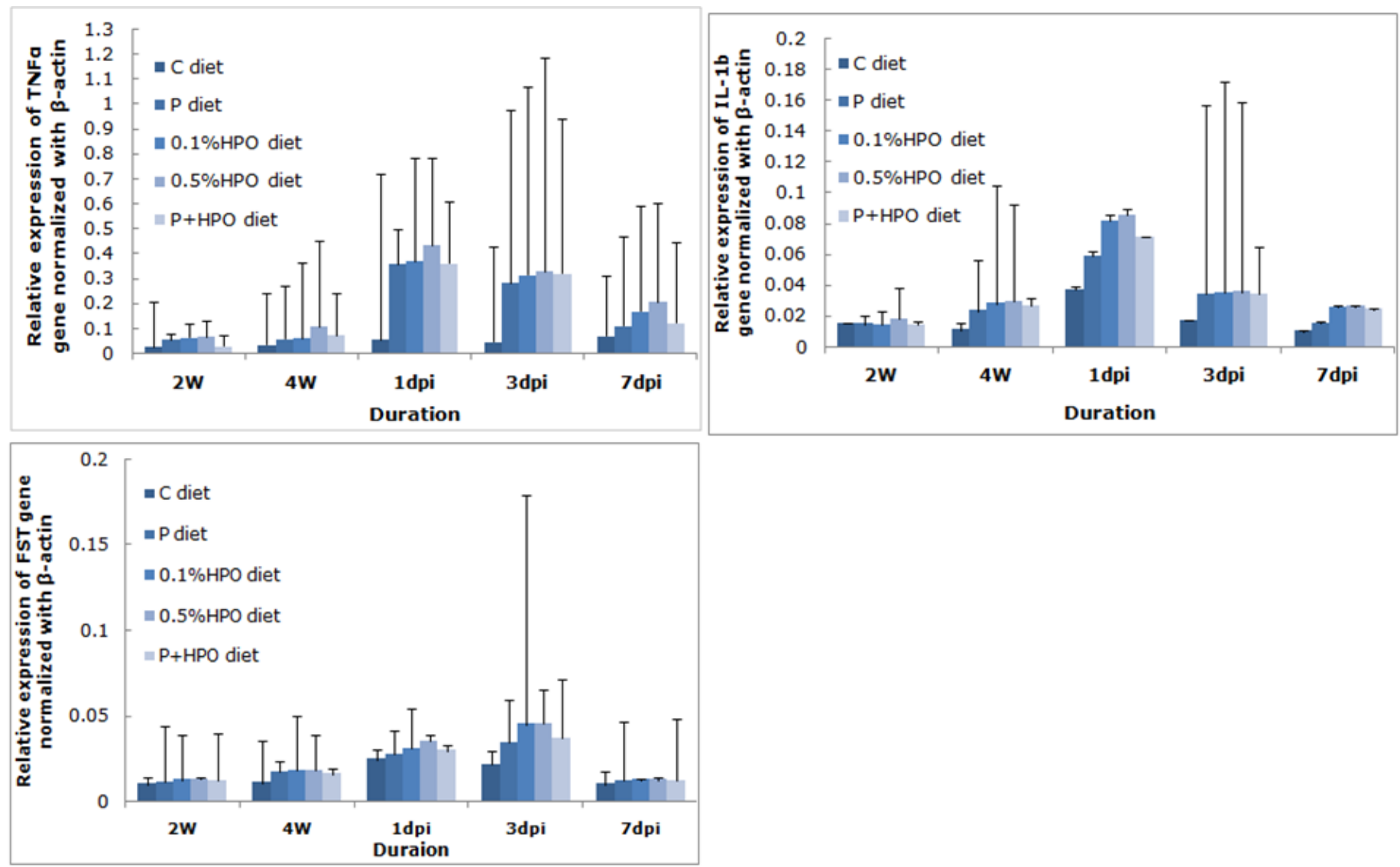

Fig. 4. Relative mRNA expression of TNFa, IL-1b, and FST gene transcripts in head kidney of rock bream, O. fasciatus, fed with control, probiotic, HPO $(0.1 \%$ and $0.5 \%)$ and P+HPO diet, by SYBR green qPCR. All samples were normalized using $\beta$-actin expression as an internal control. Relative levels of target genes mRNA were analyzed by the $2^{-\Delta \mathrm{Ct}}$ (the Ct value of the target gene minus the Ct value of the $\beta$-actin gene) method. Data are presented as mean \pm S.D.

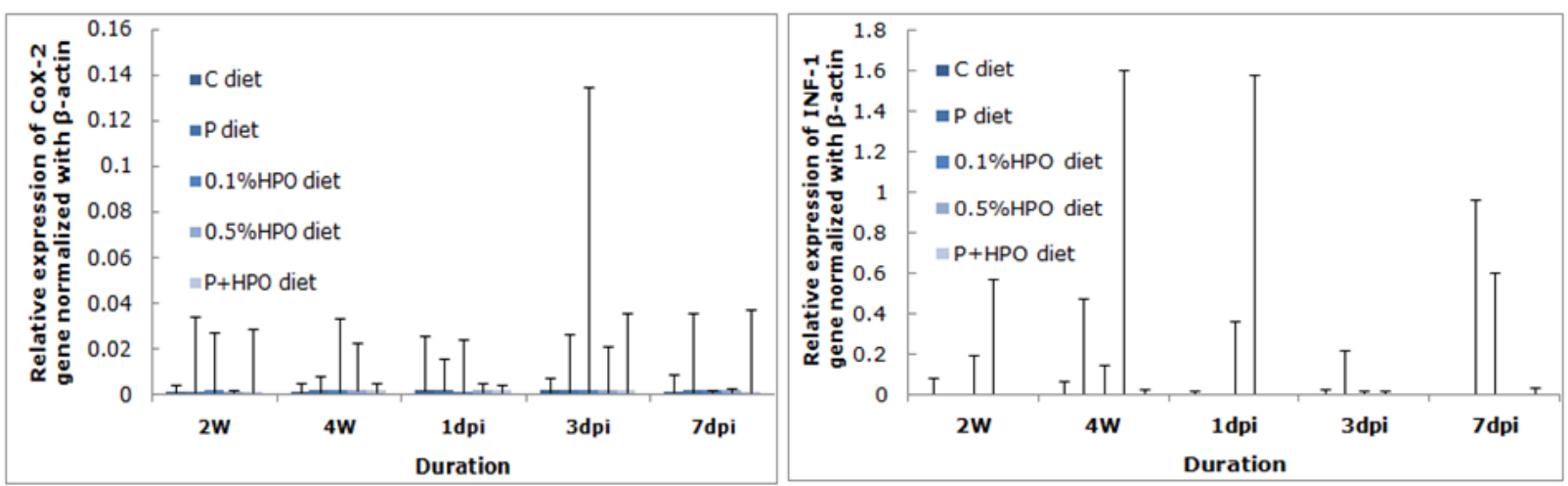

Fig. 5. Relative mRNA expression of CoX-2 and INF-1 gene transcripts in head kidney of rock bream, O. fasciatus, fed with control, probiotic, HPO $(0.1 \%$ and $0.5 \%)$ and P+HPO diet, by SYBR green qPCR. All samples were normalized using $\beta$-actin expression as an internal control. Relative levels of target genes mRNA were analyzed by the $2^{-\Delta \mathrm{Ct}}$ (the $\mathrm{Ct}$ value of the target gene minus the Ct value of the $\beta$-actin gene) method. Data are presented as mean \pm S.D.

\section{Discussion}

Hallabong peel oil (HPO) was found to be rich in monoterpene hydrocarbons such as limonene-a $(91.26 \%)$, sabinene, myrcene, $y$-terpinene, with lower proportion of aliphatic and sesquiterpene hydrocarbons which was consistent with previous reports (Choi, 2003; Tajkarimi et al., 2010). These compounds are secondary metabolites known to possess antimicrobial, antiviral, and antifungal properties (Fitzgerald et al., 2003; Schnitzler et al., 2011; Tajkarimi et al., 2010). In citrus fruits, essential oil is accumulated largely in 
the peel which is presently considered as waste in most countries, and information about the use of such hydrocarbon rich peel in fish disease management is scarce. The present study is the first to report on the dietary effect of Hallabong peel oil in growth, biochemical, and immune gene enhancement in rock bream, Oplegnathus fasciatus challenged with E. tarda.

In this study, growth performance such as weight gain, SGR, and FCR were found to increase with diets enriched with HPO. The highest level was achieved with the $0.5 \%$ HPO diet and exceeded the probiotic diet fed fish. These results are consistent with results obtained in Oreochromis mossambicus fed a diet enriched with Citrus sinensis peel oil (Acar et al., 2015) and in juvenile Labeo victorianus fed with Citrus limon peel oil (Ngugi et al., 2016). Dietary inclusion of HPO increased survival rate from $58.2 \%$ (control diet fed fish) to $93.5 \%(0.5 \%$ HPO diet fed fish), and survival rate was higher than that of probiotic diet fed fish (91.2\%).

E. tarda, a Gram negative major fish pathogenic bacterium causes edwardsiellosis disease in economically important aquaculture fish species such as tilapia, koi carp, flounder, salmon, eel, etc with clinical symptoms such as lesions, pigment loss, necrotic abscesses, bulged kidneys and internal organs (Plumb. 1999). However, in this study, all the experimental diet (HPO and probiotic diet) groups except the control diet fed fish, showed clinical symptoms with improved survival rate after challenge with the $E$. tarda pathogen. A similar result of decreased mortality after infection with $A$. hydrophila was documented in Ictalurus punctatus when fed a diet enriched with oregano essential oil (Zheng et al., 2009).

Disease resistance of fish is usually associated with humoral and cell mediated immunity (Erdal et al., 1991; Hadidi et al., 2008; Lin and Shiau, 2005). Several immune parameters were assessed in order to determine the protective effect of dietary Hallabong peel oil on disease resistance in rock bream. This study reveals increased EC and LC counts in blood, enhanced serum protein with decreased glucose levels in HPO enriched diet fed fish when compared with control diet fed rock bream. Comparable results of increased erythrocytes, leukocyte count, and serum protein levels in Lobeo rohita fingerlings (Sahu et al., 2007) and common carp (Gopalakannan and Arul, 2006) were obtained when fed with dietary herbal immunostimulants. An increase in serum protein levels is thought to be associated with a stronger innate immune response and a fundamental defense mechanism in fish (Wiegertjes et al., 1996). Such mechanisms are formed by a series of essential functions that keep host cells alive, healthy, and protected from pathogens.

In HPO enriched diet fed fish, other biochemical parameters like serum glucose, low density cholesterol and triglycerides showed a declining pattern when compared with control diet fed fish. Reduction in the serum glucose level is recognized as an important indicator of hormonal response to stressors (Morgan and Iwama, 1997). This result suggests that HPO contains compounds that reduce primary stress in fish. Previous studies have demonstrated that citrus fruit peels are more effective in lowering cholesterol and triglyceride levels in other animals as they are rich in limonene polymethoxylated flavones (Kurowska and Manthey, 2004). A similar decreasing trend was found with two liver enzymes namely AST and ALT in HPO diet fed rock bream indicating the non toxic nature of HPO as it protects the liver from damage (Giannini et al., 2005).

Lysozyme is a major defense molecule of the innate immune system which is directly linked with elevated oxygen consumption (Biller-Takahashi et al., 2013) and its reactive derivatives (i.e. hydrogen peroxide and hydroxyl radicals) which are capable of destroying invading pathogens (Neumann et al., 2001; Secombes and Olivier, 1997). Dietary intake of HPO increased the level of lysozyme and respiratory burst activity and in turn induced the release of cytokines and initiated inflammatory response in rock bream.

In fish inflammatory response, TNF-a and IL-1 $\beta$, are pro-inflammatory cytokines (Koj, 1998; Scapigliati et al., 2001) which act synergistically to mediate resistance to infections by controlling intracellular pathogen replication (Haugland et al., 2007). In the 
present study, gene expression of TNF-a and IL-1 $\beta$ were up-regulated by HPO in the head kidney of rock bream fed an HPO enriched diet. Similar constitutive expression of TNF-a in all gilthead sea bream tissues has been reported (Garcia-Castillo et al., 2002) and increases of TNF- $a$ and IL-1 $\beta$ after pathogen exposure has been also reported for different fish species (Garcia-Castillo et al., 2002; Mulder et al., 2007; Pelegrin et al., 2001). In our study we found increases of cytokine expression in all dietary treatments in the period post-infection with E. tarda. Previous studies also suggest that in fish challenged with bacterial pathogens; pro-inflammatory cytokines can be over-expressed earlier in systemic immune tissues than in local tissues were the pathogens to proliferate, as suggested by other authors (Lindenstrom et al., 2004; Poisa-Beiro et al., 2008; Sigh et al., 2004). Excessive production of pro-inflammatory cytokines is latently harmful to the host (Koj (1998). TGF- $\beta$, an important fish anti-inflammatory cytokine, is produced to inhibit excessive activation of immune response (Raida and Buchmann, 2008). In the present study, gene expression of FST was up-regulated by dietary HPO in head kidney which indicated that excessive activation of the inflammatory response was also depressed by Hallabong essential oil. The follistatin (FST) gene encodes a monomeric glycoprotein that plays a role in binding and inhibiting the function of members of the transforming growth factor (TGF)- $\beta$ superfamily. Thus, FST facilitates a wide variety of functions, ranging from muscle growth to inflammation and immunity (Tortoriello et al., 2001). A previous study reported the up-regulation ( 3.4 times) of FST gene transcript, 6 hours after infection with $E$. tarda in rock bream (Funkenstein et al., 2009). Similarly, studies in rats have shown that dietary supplementation increased expression of TGF- $\beta$, mRNA, and TGF- $\beta$ protein content (Narita et al., 1995).

The HPO enriched diet also showed increased L. planctarum cells in the intestine of $\mathrm{P}+\mathrm{HPO}$ diet fed fish when compared with the probiotic diet fed fish, indicating that the presence of HPO could improve the colonization of beneficial bacteria and in turn help to improve the health status of the fish. Gills, skin, and gastrointestinal tract have been demonstrated to be portals of entry for many microbial pathogens (Evelyn, 1996). The probiotic bacteria might be able to protect the host from pathogens by blocking the integumental attachment sites (adhesion receptors). L. planctarum colonizing epidermal mucus may originate from the intestinal tract via feces. Good adhesion ability to mucosal surfaces is a prerequisite for bacterial colonization of Lactobacillus rhamnosus to fish mucus (Nikoskelainen et al., 2001) and human mucus (Kirjavainen et al., 1998; Nikoskelainen et al., 2003; Ouwehand et al., 1999). To our knowledge, this is the first study reporting the wide ranging enhancement of probiotic bacterial colonization of $L$. planctarum in fish gut $\left(10^{1}-10^{6} \mathrm{cfu} / \mathrm{mL}\right)$. Continuous feeding of probiotic diet is essential to maintain the probiotic bacterial count in fish gut (Kim et al., 2010). The present study demonstrates that Hallobong peel oil could have a greater effect on increasing the probiotic count than probiotic feed.

The results of the present study suggest that dietary inclusion of Hallabong peel oil can enhance growth, immunity, and disease resistance in rock bream, $O$. fasciatus challenged with E. tarda. Hence, HPO has the potential to be used in aquaculture for fish disease prevention and management particularly against edwardsiellosis.

\section{Acknowledgments}

The authors gratefully acknowledge 'The Leading Human Resource Training Program of Regional Neo industry' through the National Research Foundation of Korea (NRF) funded by the Ministry of Science, ICT and future planning (2016H1D5A1911152).

\section{References}

Acar U., Kesbic O.S., Yılmaz S., Gültepe N. and A. Türker, 2015. Evaluation of the effects of essential oil extracted from sweet orange peel (Citrus sinensis) on growth rate of tilapia (Oreochromis mossambicus) and possible disease resistance against Streptococcus iniae. Aquaculture, 437:282-286. 
Awad E. and B. Austin, 2010. Use of lupin, Lupinus perennis, mango, Mangifera indica, and stinging nettle, Urtica dioica, as feed additives to prevent Aeromonas hydrophila infection in rainbow trout, Oncorhynchus mykiss (Walbaum). J. Fish Dis. 33:413-420.

Bae J.S., Shim S.H., Hwang S.D., Kim J.-W., Park D.-W. and C.I. Park, 2013. Molecular cloning and expression analysis of interleukin (IL)-15 and IL-15 receptor a from rock bream, Oplegnathus fasciatus. Fish Shellfish Immunol., 35:1209-1215.

Biller-Takahashi J.D., Takahashi L., Saita M., Gimbo R.Y. and E.C. Urbinati, 2013. Leukocytes respiratory burst activity as indicator of innate immunity of pacu, Piaractus mesopotamicus. Brazilian J Biol., 73:425-429.

Bhuvaneswari R. and Balasundaram C., 2006. Traditional Indian herbal extracts used in vitro against growth of the pathogenic bacteria - Aeromonas hydrophila. Isr. J. Aquacult.-Bamidgeh, 58(2):89-96.

Cantas, L., Shah, S. Q. A., Cavaco, L. M., Manaia, C. M., Walsh, F., Popowska, M., et al. 2013. A brief multi-disciplinary review on antimicrobial resistance in medicine and its linkage to the global environmental microbiota. Frontiers in Microbiology, 4:96.

Choi H.S. and M. Sawamura, 2001. Volatile flavour compounds of ripe and overripe kimilans (Citrus flaviculpus Hortic. Ex Tanaka) in comparison with Hyuganatsu (Citrus tamurana Hort. ex Tanaka). Biosci. Biotechnol. Biochem. 65:48-55.

Choi H.S., 2003. Character impact odorants of Citrus Hallabong ((C. unshiu Marcov $\times$ C. sinensis Osbeck $\times$ C. reticulata Blanco) cold pressed peel oil. J. Agr. Food Chem. 51:2687-2692.

Citarasu T., 2010. Herbal biomedicines: a new opportunity for aquaculture industry. Aquacult. Int. 18:403-414.

Dimitroglou A., Merrifield D.L., Carnevali O., Picchietti S., Avella M., Daniels C., et al. 2011. Microbial manipulations to improve fish health and production - a Mediterranean perspective. Fish Shellfish Immunol. 30:1-16.

Ellis, A., 1990. Lysozyme assay in techniques in fish immunology. In: Stolen JS, Fletcher TC, Anderson DP, Robertson BS, Van Muisvinkel WR, editors. SOS Publications, Fair Haven, New Jersey, USA.

Erdal J.L., Evensen O. and O.K. Kaurstad, 1991. Relationship between diet and immune response in Atlantic salmon (Salmo salar L.) after feeding various levels of ascorbic and omega-3 fatty acids. Aquaculture, 98:363-379.

Evelyn T.P., 1996. Infection and disease. In: Iwama G, Nakanishi T, editors. The fish immune system. Academic Press, San Diego (California).

FAO., 2013. FISH TO 2030 Prospects for Fisheries and Aquaculture WORLD BANK REPORT NUMBER 83177-GLB. Fisheries and Aquaculture Department, FAO, Rome.

Fitzgerald D.J., Stratford M. and A. Narbad., 2003. Analysis of the inhibition of food spoilage yeasts by vanillin. Int J Food Microbiol., 86:113-122.

Funkenstein B., Rebhan Y. and T. Skopal, 2009. Molecular cloning and characterization of follistatin in the gilthead sea bream, Sparus aurata. Mol. Biol. Rep. 36:501-511.

Ganguly S., Paul I., Mukhopadhayay K.S., 2010. Application and Effectiveness of Immunostimulants, Probiotics, and Prebiotics in Aquaculture: A Review. Isr. J. Aquacult.Bamidgeh, 62(3):130-138.

García-Castillo J., Pelegrín P., Mulero V. and J. Mesenguer, 2002. Molecular cloning and expression analysis of tumor necrosis factor a from a marine fish reveal its constitutive expression and ubiquitous nature. Immunogenetics, 54:200-207.

Giannini, Edoardo G., Roberto Testa and Vincenzo Savarino, 2005. "Liver Enzyme Alteration: A Guide for Clinicians." Canadian Medical Association Journal, 172.3:367379. PMC. Web. 11 Nov. 2016.

Gopalakannan, A. and V. Arul, 2006. Immunomodulatory effects of dietary intake of chitin, chitosan and levamisole on the immune system of Cyprinus carpio and control of Aeromonas hydrophila infection in ponds. Aquaculture, 225:79-187.

Hadidi S., Glenney G.W., Welch T.J., Silverstein J. and G.D. Wiens, 2008. Spleen size predicts resistance of rainbow trout to Flavobacterium psychrophilum challenge. J Immunol, 180:4156-4165. 
Harikrishnan R., Rani M.N. and C. Balasundaram, 2003. Hematological and biochemical parameters in common carp, Cyprinus carpio, following herbal treatment for Aeromonas hydrophila infection, Aquaculture, 221:41-50.

Haugland O., Mercy I.S., Romoren K., Torgersen J. and O. Evensen, 2007. Differential expression profiles and gene structure of two tumor necrosis factor-a variants in Atlantic salmon (Salmo salar L.). Mol. Immunol. 44, 1652-1663.

Herath L.P.B., Priyathilaka T.T., Elvitigala A.S., Umasuthan N. and J. Lee, 2015. The Molecular Profiling of a Teleostan Counterpart of Follistatin, Identified from Rock Bream Oplegnathus fasciatus which Reveals its Transcriptional Responses against Pathogenic Stress. Fish Aquat. Sci. 18:273-281.

Hong S., Jin J.W., Park J.H., Kim J.K. and H.D. Jeong, 2016. Analysis of proinflammatory gene expression by RBIV infection in rock bream, Oplegnathus fasciatus. Fish Shellfish Immunol., 50:317-326.

Kim H.S., Lee S.H. and J.S. Koh, 2006. Physicochemical properties of Hallabong Tangor (Citrus Kiyomixponkan) cultivated with heating. Korean J. Food Preserv., 13:611615.

Kim J.S., Harikrishnan R., Kim M.C., Balasundaram C. M.S. Heo, 2010. Dietary administration of Zooshikella sp. to enhance the innate immune response and disease resistance of Paralichthys olivaceus against Streptococcus iniae. Fish Shellfish Immunol., 29:104-110.

Kirjavainen P.V., Ouwehand A.C., Isolauri E. and S.J. Salminen, 1998. The ability of probiotic bacteria to bind to human intestinal mucus. J. Appl. Microbiol., 85:769-777.

Koj A., 1998. Termination of acute-phase response: role of some cytokines and antiinflammatory drugs. Gen. Pharmacol., 31:9-18.

Kurowska E.M. and J.A. Manthey, 2004. Hypolipodemic effects and absorption of citrus polymethoxylated flavones in hamsters with diet-induced hypercholesterolemia. $J$. Agri. Food Chem., 52:2879-2886.

Lee C., Oh H., Han S. and S. Lim, 2012. Effects of hot air and freeze drying methods on physicochemical properties of citrus 'Hallabong' powders. Food Sci. Biotechnol., 21:1633-9.

Lin J., Opoku A.R., Geheeb-Keller A.K., Hutchings A.D., Terblanche S.E., Jager A.K. and J. Van Staden, 1999. Preliminary screening of some traditional Zulu medicinal plants for anti-inflammatory and anti-microbial activities. J. Ethanophama., 68:267-274.

Lin M.F. and S.Y. Shiau, 2005. Dietary L-ascorbic acid affects growth, nonspecific immune responses and disease resistance in juvenile grouper, Epinephelus malabaricus. Aquaculture, 244:215-221.

Lindenstrom T., Buchmann K. and C.J. Secombes, 2004. Expression of immune genes in rainbow trout skin induced by Gyrodactylus derjavini infections. Immunopathology, 97:137-48.

Livak, K.J. and T.D. Schmittgen, 2001. Analysis of relative gene expression data using Real-Time quantitatiove PCR and the $2^{-\Delta \Delta C}$ method. Methods. 25:402-408.

Massada Y., 1976. Analysis of Essential Oils by Gas Chromatography and Mass Spectrometry. Wiley, New York.

Morgan J.D. and G.K. Iwama, 1997. Measurements of Stressed States in the Field. Cambridge University Press, Cambridge, UK.

Mulder I.E., Wadsworth S. and C.J. Secombes, 2007. Cytokine expression in the intestine of rainbow trout (Oncorhynchus mykiss) during infection with Aeromonas salmonicida. Fish Shellfish Immunol., 23:747-59.

Narita I., Border W.A., Ketteler M., Ruoslahti E. N.A. Noble, 1995. L-Arginine may mediate the therapeutic effects of low protein diets. Proc. Natl. Acad. USA, 92:45524556.

Neumann N.F., Stafford J.L., Barreda D., Anisworth A.J. and M. Belosevic, 2001. Antimicrobial mechanism of fish phagocytes and their role in host defence. Dev. Comp. Immunol., 25:807-825.

Ngugi C.C., Oyoo-Okoth E. and Mucai Muchiri, 2016. Effects of dietary level of essential oil (EO) extract from bitter lemon (Citrus limon) fruit peels on growth, 
biochemical, haemato-immunological parameters and disease resistance in Juvenile Labeo victorianus fingerlings challenged with Aeromonas hydrophila, Aquacult Res., 1-13. Nikoskelainen S., Ouwehand A., Bylundm G., Salminen S. and E.M. Lilius, 2003. Immune enhancement in rainbow trout (Oncorhynchus mykiss) by potential probiotic bacteria (Lactobacillus rhamnosus), Fish Shellfish Immunol., 15:443-452.

Nikoskelainen S., Salminen S., Bylund G. and A.C. Ouwehand, 2001. Characterization of the properties of human- and dairy-derived probiotics for prevention of infectious diseases in fish. Appl. Environ. Microbiol., 67:2430-5.

Ouwehand A.C., Niemi P. and S.J. Salminen, 1999. The normal faecal microflora does not affect the adhesion of probiotic bacteria in vitro. FEMS Microbiol. Lett., 177:35-38.

Pelegrin P., García-Castillo J., Mulero V. and J. Mesenguer, 2001. Interleukin-1b isolated from a mairne fish reveals up-regulated expression in macriphages following activation with lipopolysaccharide and lymphokines. Cytokine, 16:62-72.

Pieters N., Brunt J., Austin B. and A.R. Lyndon, 2008. Efficacy of in-feed probiotics against Aeromonas bestiarum and Ichthyophthirius multifiliis skin infections in rainbow trout (Oncorhynchus mykiss, Walbaum). J. Appl. Microbiol., 105:723-732.

Plumb J.A., 1999. Edwardsiella septicaemias. Fish diseases and disorders. Volume 3: Viral, bacterial and fungal infections. 479-521.

Poisa-Beiro L., Dios S., Montes A., Aranguren R., Figueras A. and A. Novoa, 2008. Nodavirus increases the expression of $\mathrm{Mx}$ and inflammatory cytokines in fish brain. Mol. Immunol., 45:218-25.

Raida M.K. and K. Buchmann, 2008. Bath vaccination of rainbow trout (Oncorhynchus mykiss Walbaum) against Yersinia ruckeri: effects of temperature on protection and gene expression. Vaccine, 26:1050-1062

Sahu S., Das B.K., Pradhan J., Mohapatra B.C., Mishra B.K. and N. Sarangi, 2007. Effect of Magnifera indica kernel as a feed additive on immunity and resistance to Aeromonas hydrophila in Labeo rohita fingerlings. Fish Shellfish Immunol., 23:109-118.

Scapigliati G., Buonocore F., Bird S., Zou J., Pelegrin P., Falasca C., et al. 2001. Phylogeny of cytokines: molecular cloning and expression analysis of sea bass Dicentrarchus labrax interleukin-1 $\beta$, Fish Shellfish Immunol., 11:711-726.

Schnitzler, P., Astani, A. and J. Reichling, 2011. Screening for antiviral activities of isolated compounds from essential oils. Evidence Based Complimentary and Alternative Medicine Article ID 253643.

Secombes, C.J. and G. Olivier, 1997. Furunculosis. Academic Press, New York. Pp. 269-296.

Shak J.R., Whitaker J.A., Ribner B.S. and E.M. Burd, 2011. Aminoglycoside-resistant Aeromonas hydrophila as part of a polymicrobial infection following a traumatic fall into fresh water. J. Clin. Microbiol. 49:1169-1170.

Sheikhlar A., Alimon A.R., Daud H., Saad C.R., Webster C.D., Meng G.Y. and M. Ebrahimi, 2014. White Mulberry (Morus alba) Foliage Methanolic Extract Can Alleviate Aeromonas hydrophila Infection in African Catfish (Clarias gariepinus). The Scientific World Journal 592709.

Sigh J., Linderstrom T. and K. Buchmann, 2004. Expression of pro-inflammatory cytokines in rainbow trout (Onchorynchus mykiss) during an infection with Ichthyophthirius multifiliis. Fish Shellfish Immunol., 17:75-86.

Song H.S., Park Y.H. and D.G. Moon, 2005. Volatile flavor properties of Hallabong grown in open field and green house by GC/GC-MS and sensory evaluation. J Korean Soc Food Sci. Nutr., 34:1239-1245.

Subramanian D., Jang Y.H., Kim D.H., Kang B.J. and M.S. Heo, 2013. Dietary effect of Rubus coreanus ethanolic extract on immune gene expression in white leg shrimp, Penaeus vannamei, Fish Shellfish Immunol., 35(3):808-814.

Tajkarimi M.M., Ibrahim S.A. and D.O. Cliver, 2010. Antimicrobial herb and spice compounds in food. Food Control, 21:1199-1218.

Tortoriello D.V., Sidis Y., Holtzman D.A., Holmes W.E. and A.L. Schneyer, 2001. Human follistatin-related protein: a structural homologue of follistatin with nuclear localization. Endocrinology, 142, 3426-3434. 
Wiegertjes G.F., Stet R.J.M., Parmentier H.K. and W.B. Van Muiswinkel, 1996. Immunogenetics of disease resistance in fish; a comparable approach. Dev. Comp. Immunol. 20:365-381.

Wiens G.D., 2009. Microbial Genomics of Aquaculture Pathogens. In: Overturf, K. (ed.) Molecular Research in Aquaculture. Wiley-Blackwell, Ames, Iowa, USA.

Zheng Z.L., Tan J.Y.W., Liu H.Y., Zhou X.H., Xiang X. and K.Y. Wang, 2009. Evaluation of oregano essential oil (Origanum heracleoticum L.) on growth, antioxidant effect and resistance against Aeromonas hydrophila in channel catfish (Ictalurus punctatus). Aquaculture, 292:214-218. 